\title{
DETERMINING SMALL AND MEDIUM INDUSTRY MAIN PRODUCT IN BANYUMAS DISTRICT
}

\author{
Muhammad Unggul Abdul Fattah ${ }^{* 1}$, Arief Satria**), and Gendut Suprayitno ${ }^{* * *)}$ \\ *) The Indonesian National Counter-Terrorism Agency (BNPT) \\ BNPT Kompleks IPSC, Jl. Anyar Desa Tangkil Sentul, Bogor 16180 \\ ${ }^{* *}$ Department of Communication and Community Developmen, Faculty of Human Ecology, Bogor Agricultural University \\ Jl. Kamper, Campus IPB Darmaga, Bogor, 16680 \\ ***) Program Master of Industrial Engineering, National Institute of Science and Technology \\ Campus III ISTN, Jl. PLN Durentiga, Pasar Minggu, Jakarta 12760
}

\begin{abstract}
The purpose of this study was to determine the main product out of several alternative options of small and medium industries (IKM) main product in Banyumas District. The study was conducted by using in-depth interviews with respondents who were skillful experts with the authority to establish the main product in Banyumas. The criteria used in determining the main product come from 12 criteria set out in the Regulation of the Ministry of Home Affairs of Republic of Indonesia Number 9 of 2014. The establishment of criteria values was determined by using AHP and main product assessment with MPE. The results of the assessment indicate that the first priority of main product Banyumas is the coconut sugar. Coconut sugar products are supported by the abundance of natural resources of raw materials, while the other main product priorities include mendoan tempeh and getuk gerbong which are typical products of Banyumas. Both products are products that will facilitate economic growth through tourism as a specific sector for culinary products of Banyumas.
\end{abstract}

Keywords: main product, small and medium industries (IKM), AHP, MPE

\begin{abstract}
ABSTRAK
Tujuan dari penelitian ini adalah menentukan produk unggulan daerah dari beberapa alternatif pilihan produk Industri Kecil dan Menengah (IKM) potensi di kabupaten Banyumas. Penelitian dilakukan menggunakan metode wawancara mendalam terhadap responden ahli yang memiliki kemampuan, peran serta wewenang dalam penentuan produk unggulan daerah Kabupaten Banyumas. Kriteria yang digunakan dalam penentuan produk unggulan daerah berasal dari 12 kriteria yang ditetapkan dalam Peraturan Menteri Dalam Negeri Republik Indonesia Nomor 9 Tahun 2014. Penentuan bobot kriteria dilakukan dengan menggunakan AHP dan penilaian produk unggulan daerah menggunakan MPE. Hasil dari penilaian menunjukkan bahwa prioritas pertama produk unggulan daerah kabupaten Banyumas adalah gula kelapa. Produk gula kelapa ditunjang oleh kelimpahan sumber daya alam bahan baku, Prioritas produk unggulan daerah lain adalah tempe mendoan dan getuk gerbong yang merupakan produk khas kabupaten Banyumas. Kedua produk tersebut merupakan produk yang mampu mendorong pertumbuhan ekonomi melalui sektor pariwisata sebagai produk kuliner spesifik kabupaten Banyumas.
\end{abstract}

Kata kunci: produk unggulan daerah, Industri Kecil dan Menengah (IKM), AHP, MPE

${ }^{1}$ Corresponding author:

Email:unggulfattah@yahoo.com

\section{INTRODUCTION}

Competitiveness is one trait that is highly required in competing within free trade market. The phenomenon of this trait will be directly related to the development of the construction going on in a particular area. According to Daryanto (2004), the concept of development in a region must adhere to the conditions of the area (inward looking). The selection of priority development refers to the needs of the community in which the welfare of the society is the major priority. The concept of development of various dimensions applied to a region often comes across the fact that the concept requires modification or adjustment to suit to the local characteristics (local specific). Economic development which is only pursuing the high growth by relying solely in the comparative advantages; e.g. abundant natural resources, cheap labor wages, and 
strategic position, however, in this time, is difficult to maintain any longer. Competitiveness cannot be obtained from factors like low wages or low interest rate, yet it must also be obtained from the ability to perform continuous improvement and innovation.

In the era of local autonomy, the authority of the local head to manage the resources within its territory aims to be used to trigger the industrial developmental strategy whose formulation should involve elements of the government including the local government along with all business actors and related parties. The fundamental objective of local economic development is the improvement of social welfare in the region through an increased competitiveness. According to Muchdie (2000), the advantage of competitiveness in an area will be formed when the region has a core competence which can be distinguished from other areas. This local core competence can be applied through the creation of various production factors that can lead to far better achievement of the area than its local competitors. To support the core competence areas, the area potential needs to be optimally developed into a competitive main product and to improve the welfare of the society in accordance with the conditions and signatures of the area.

According to (Alfita, 2011), the local main products do not need to be made from the high-tech industries or with high investment. Nevertheless, a main product can be made from local products. Steps need to be taken to ensure the main product development goals can be achieved; i.e. increasing the capacity of local institutions and documenting the main product development in the local planning documents (Ministry of Home Affair, 2014). Therefore, to support the core competencies, the main product needs to be determined as being able to improve the welfare of the people in Banyumas District. The establishment of main product is highly important because main product are products, both in the form of goods and services, produced by cooperations, potential small-medium scaled businesses which need to be developed by utilizing all resources owned by the region; i.e. natural resources, human resources and local culture, as well as by bringing in revenue for the community and the government, and these products are expected to be the economic power for the region and local communities and to be the potential products with competitiveness, marketability, thrust and capacity to penetrate the global market.
As a district with the second rank of competitiveness in level II district of Central Java Province, after Magelang District in 2010 and based on the BPMD study in Millah (2013), the establishment of main product Banyumas District will provide major contribution to local economic growth. In establishing the main product of Banyumas, there are two (2) issues which must be resolved. The first problem is how to calculate the weight of main product selection criteria in Banyumas, and the second one is whether the result of the main product establishment is based on the assessment of established criteria. Completion of both problems will provide a basis to establish the main product Banyumas based on the priorities of established criteria in accordance with the conditions and the potentials that exist in Banyumas District. The final goal of this study was to determine the main product Banyumas to be utilized as the basis for IKM (SMCB) developmental strategy in Banyumas District.

\section{METHOD}

This research was conducted in Banyumas District Central Java with purposive selection based on: (1) consideration of the potential products featured in Banyumas District; (2) the availability of the necessary data and support from the experts of policy makers. The instruments used in this study were in depth interviews by using a questionnaire that was designed suited to the purpose of the research on the expert respondents with the ability and the role of the authority in establishing main product in Banyumas. The selection of respondents was in line with the reference to these criteria: (1) expertise based on experience and authority comes from stakeholders; both central and local levels; (2) expertise based on data-based experience; (3) expertise based on experience in the business world; (4) expertise based on the academic analysis capabilities in the area of research. On the basis of these criteria, the expert respondents determining the main product in Banyumas come from the General Director of IKM, the Ministry of Industry, Department of Industry, Trade and Cooperation, Department of Agriculture, Forestry, and Agriculture, the Chair of Commerce and Industry (Kadin) in Banyumas, Institute of Community Services in Soedirman University, Board of Investment and Licensing Services (CEW) in Banyumas, and Local Development Planning Board (Bappeda) Banyumas. 
The establishment of main product in Banyumas was based on the assessment by expert respondents by using basic 12 (twelve) criteria set by the Ministry of Home Affairs (2014); i.e. (1) labor absorption where the main products are manufactured by utilizing skilled labor in the area of production in order to give effects on creating jobs and income for the local communities; (2) contribution to the economy where a product has an economic value providing benefits to the consumers, has a relation to the front and back, and gives a multiplier economic effect as well as provides economic benefits to all stakeholders and areas that produce the excellent products; (3) The local economic-based sector is a local main product that falls into the category of the basic sector in PDRB/GDP and gives the largest contribution to the local economy; (4) Renewability indicates that the main products are not minerals, yet they are gained by utilizing renewable and environmentally friendly raw materials. Minerals cannot be included as main product despite their great contribution to the local economy; (5) the socio-cultural elements in creating, producing and developing a main product utilize the talents and community institutions which are built and developed on the basis of local knowledge in reference with the characteristics and cultural heritages from generations as well as from local socio-cultural conditions; (6) Market availability means the main product are able to be absorbed in the local and national markets as well as have the potential to enter global markets; (7) Guaranteed availability of raw materials which are acquired with competitive prices and guaranteed continuity and environmentally friendly; (8) Capital is the availability and sufficiency of funds for the smooth running business as the investment and working capital needs; (9) Facilities and infrastructure for production are the advantages for main product employers to acquire facilities and infrastructure for production at a competitive price level and are easy to obtain; (10) Relevant and useful technology with elements that are not easily imitated; (11) Business management is the ability to manage the business in a professional manner by utilizing the talents and community institutions; and (12) The ability to provide value-added and profitable business. All the criteria are used to determine the main product in Banyumas as they are already used by Permana (2015) in determining the main products of Bandung District.
Each criterion to determine the main product was measured by using Analytical Hierarchy Process (AHP). AHP is used in some types of analysis, including determining the prioritized strategies to improve the quality of edamame (Wardani et al. 2015), measuring the main product criteria in the prioritization of IKM in Bandung (Permana, 2015), and determining the prioritized industrial development strategy of palm sugar (Evalia, 2015). After the measurement of each main product criterion was obtained, the assessment by each respondent of experts to determine main product of IKM was conducted by using MPE. The MPE in the product prioritization had been used as it was used in choosing which types of processed wood products are prospective compared to some other products produced by a company (Hamzah et al. 2005), in analyzing the potential sites of agro-industry development leading commodity (Antuli, 2007), in selecting highland vegetable products (Slamet et al. 2011), and in analyzing the choice of the main products of Bandung District (Permana, 2015). The advantages of the establishment of main product IKM by utilizing Exponential Comparative Method (MPE) are as follows: (1) to reduce possible biases in the analysis; (2) the value of the total score of each alternative decision would be significantly different because of the exponential function.

\section{RESULTS}

The first results of this study are the magnitude of the weight of the criteria in establishing main product IKM in Banyumas. The weight of these criteria describes the priority given by the expert respondents and processed by using AHP. The assessment of expert respondents on potential IKM products in Banyumas used the criteria, and they were processed by using MPE to determine the main product in Banyumas District.

Prior to the establishment of the main product, inventory was conducted throughout the whole potential products of IKM in Banyumas in advance. The results of the inventory of potential industry products in Banyumas are presented in Table 1. 
Table 1. Lists of main product of IKM in Banyumas

\begin{tabular}{lc}
\hline \multicolumn{1}{c}{ IKM potential products } & Categories \\
\hline Palm sugar & IKM of agroindustry \\
Essential oils & IKM of agroindustry \\
Batik Banyumas & IKM of handcrafts \\
Fried getuk & IKM of food \\
Mendoan soybean cake & IKM of food \\
Soybean crackers & IKM of food \\
Soybean tofu & IKM of food \\
Nopia/mino & IKM of food \\
Lanting & IKM of food \\
Jenang/dodol & IKM of food \\
Noodle crackers & IKM of food \\
Wood processing & IKM of forest products \\
Wooden furniture & IKM of forest products \\
Bamboo handcrafts & IKM of forest products \\
Red bricks & IKM of building materials \\
Roof tiles & IKM of building materials \\
\hline
\end{tabular}

The inventory results of potential IKM products in Banyumas obtained 16 (sixteen) products. 2 (two) products; i.e. coconut sugar and essential oils are classified from the agro-industry IKM processing raw materials to intermediate products. One of the 16 products is hand-crafted products, e.g. Batik Banyumas. IKM of the forest product processing in Banyumas District has the potential to be developed including wood processing, furniture and bamboo handicrafts. IKM of building material was also assessed to be potential in triggering the competitiveness in Banyumas. The majority of potential IKM products in Banyumas is dominated by food product IKM i.e. tempe mendoan, fried getuk, soybean crackers, soybean tofu, nopia/ mino, lanting, jenang/dodol, and noodle crackers. The whole potential products will be selected by the expert respondents and their priorities are determined as Main product of Banyumas.

\section{Determination of Main Product in Banyumas}

The first step in determining the main product IKM Banyumas District is to measure main product criteria conducted by the expert respondents by using AHP. All criteria were organized into a hierarchy to determine the prioritized main product criteria as presented in Figure 1. By using this structure, the results of the assessment of the experts were then synthesized into a single measurement. The synthesis results for the weight of each main product criterion are presented in Figure 2.

From the results of the measurement of each main product criterion, it can be seen that the employment $(0,180)$ is the primary consideration in choosing main product. Direct employment will boost economic growth in a region that will improve the welfare of the population. On the other hand, the availability of labor is able to meet the specific competencies required to be built because the correlation analysis has a significant relationship to the performance of SMEs as well as the individual performance of the workers themselves (Ardiana et al. 2010; Salmah, 2012). The economic contribution $(0,147)$ becomes the criterion with the second largest value. Expectations of local stakeholders with the determination of the macro economic main product areas can be improved. The economy-based sector $(0,130)$ became the third consideration in determining the main product. Main product can thrive if the product could become a sector basis in the region supported by the development of efficiency, biophysical growth superiority, and socio-economic conditions of society.

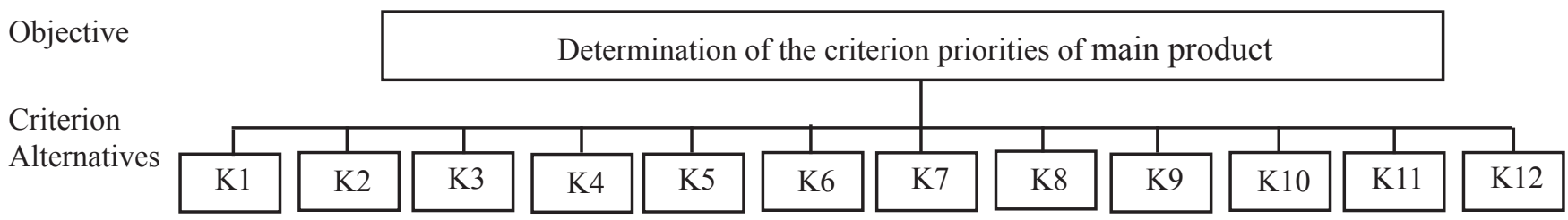

Description:
K1: Labor absorption
K2: Economy contribution
K5: Social Culture
K6: Market availability
K3: Economy-based sector
K4: Renewable
K7: Raw materials
K8: Capital

K9: Production infrastructure and facilities

K10: Technology

K11: Business Management

K12: Price

Figure 1. Hierarchy of determination of main product criterion weight by using AHP 

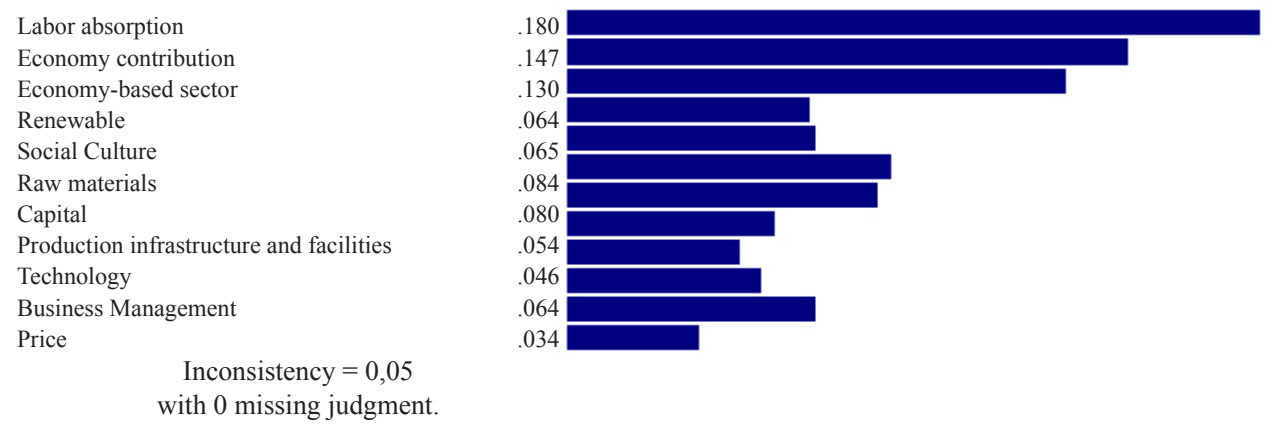

Figure 2. Synthesis of each criterion weight of main product

After obtaining the weight of each criterion of main product, an assessment was carried out towards the potential products in Banyumas District. The assessment was carried out by using MPE. MPE calculation results for the determination of main product Banyumas are presented in Table 2.

Based on the assessment by the experts, the prioritized main product of IKM in Banyumas District include coconut sugar products which have great potentials. Coconut sugar produced by the Banyumas District contributes up to $70 \%$ of the national supply of palm sugar (Suliyanto et al. 2013). In addition, the Indonesian palm sugar production reaches 120.000 tonnes per year which is the largest in the world. The second largest producer with a production capacity of 15.000 tons is Thailand, followed by India and the Philippines (Mustaufik, 2010). This product cannot be separated from the support of agricultural areas in Banyumas District that have great potentials of natural resources, thus, supporting the activities of the processing industries by using agricultural resources and the services industry. The coconut sugar industry run by the local community is called a household industry which absorbs labor and uses raw materials from the surroundings (Suliyanto et al. 2013).

Coconut sugar is able to encourage the diversification of farming as an effort to increase farmers' income (Tarigans, 2005; Mahmud, 2008), for agro-industry of coconut sugar adds better values (Djoni and Sukandar, 2013; Sukiman et al. 2007). In the development of main product IKM of coconut sugar deres which relies on oil plantations as a source of raw materials, the framework of agro-industry development in the agropolitan should not forget that the policy alternative suited to avoid over-use of land production is the changing policy of inputs and technology (Pranoto et al. 2006).
The second and third ranks of the priority determination of main product contain mendoan tempe products and fried getuk. Both of these products are typical products of Banyumas which can also be used as a frontrunner in driving the local economy, especially to support the tourism sector (Maya Banyumas, 2012). Foods which have the ability to enhance the sustainability and uniqueness of tourist destinations strengthen the economy of the area and hospitality of a local image building (Du Rand et al. 2003; Everett and Aitchison, 2008). Tempe mendoan and fried getuk are directly or indirectly related to Banyumas District, and this will encourage and attempt the travelers to taste and try Banyumas culinary because the foods can be utilized to improve the branding of tourist destinations (Boyne et al. 2003).

In the concept of local competitiveness, main product developed optimally through a variety of policy supports generates the need of related and supporting industries in the region. Porter (1998) showed that a small number of industries with high competitiveness contributes to economic activity in a geographical area and also gives the largest contribution to exports out of the region. Through the determination of main product, the local government could focus more on coordinating and integrating the sector or sub-sector of the economy that will increase the competitiveness of the region.

\section{Managerial Implication}

Based on these results, there are several managerial implications shaping the policies that can support the development of main product IKM of coconut sugar in Banyumas District; i.e. (1) Incorporating development planning of main product IKM of coconut sugar in the Medium Term Development Plan (RPJMD) Banyumas and Strategic Plan of Department of Agriculture, 
Forestry and Estate Corps, and Department of Industry, Trade and Cooperatives; (2) Establishing a partnership between farmers of deres coconut, coconut sugar of IKM, and related and supporting industries; (3) Developing the potential coconut deres raw materials through improvement techniques of cultivation which are more advanced, efficient and environmentally friendly as well as incentives for those who apply it; and (4) Improving the quality and skills of the workforce available to support main product IKM of coconut sugar in Banyumas District through community development to form sustainable agro-industries.

\section{CONCLUSIONS AND RECOMMENDATIONS}

\section{Conclusions}

The largest weight on the criteria to determine the main product of IKM in Banyumas is the employment absorption rate. The high rate of labor absorption of main product can directly give benefit on the improvement of people's welfare. In addition, the absorption of a large workforce can provide greater employment opportunities in the area.
The largest value of the expert respondents to determine the main product of IKM in Banyumas was given to coconut sugar. Coconut sugar product is supported by the availability of abundant raw materials of deres coconut in Banyumas District. Main product of coconut sugar in Banyumas District has also contributed a large level of labor absorption ranging from deres coconut farmers, artisans/producers of palm sugar, and the marketing process. Ranked second and third after the main product Banyumas are mendoan soybean cake and fried getuk. Both products are the typical products of Banyumas driven from the tourism sector.

\section{Recommendations}

The method of determining main product by referring to the expert assessment and using the criteria set out in the Regulation of the Minister of Home Affairs No. 9 of 2014 can be used as one of the methodologies to support the local competitiveness when there is a limitation in economic as well as specific product data in the area.

Table 2. Results of MPE calculation in determining main product in Banyumas

\begin{tabular}{|c|c|c|c|c|c|c|c|c|c|c|c|c|c|}
\hline \multirow{2}{*}{ Commodities } & \multicolumn{12}{|c|}{ Product values based on criteria } & \multirow{2}{*}{$\begin{array}{l}\text { Total of } \\
\text { values }\end{array}$} \\
\hline & K1 & $\mathrm{K} 2$ & K3 & K4 & K5 & K6 & $\mathrm{K} 7$ & $\mathrm{~K} 8$ & K9 & K10 & K11 & $\mathrm{K} 12$ & \\
\hline Palm sugar & 5 & 4 & 5 & 4 & 5 & 5 & 5 & 3 & 5 & 5 & 5 & 5 & 13,67 \\
\hline Essential oils & 5 & 2 & 3 & 2 & 2 & 3 & 5 & 3 & 4 & 5 & 2 & 5 & 13,24 \\
\hline Batik Banyumas & 5 & 2 & 4 & 2 & 5 & 3 & 4 & 4 & 4 & 3 & 2 & 4 & 13,31 \\
\hline Fried getuk & 5 & 4 & 3 & 3 & 4 & 4 & 5 & 3 & 3 & 3 & 3 & 4 & 13,44 \\
\hline $\begin{array}{l}\text { Mendoan soybean } \\
\text { cake }\end{array}$ & 5 & 4 & 4 & 3 & 4 & 5 & 5 & 5 & 3 & 3 & 3 & 3 & 13,52 \\
\hline $\begin{array}{l}\text { Soybean cake } \\
\text { crackers }\end{array}$ & 5 & 4 & 4 & 3 & 4 & 3 & 3 & 3 & 3 & 4 & 3 & 4 & 13,42 \\
\hline Soybean tofu & 5 & 3 & 4 & 3 & 4 & 4 & 5 & 3 & 3 & 3 & 3 & 3 & 13,42 \\
\hline Nopia/mino & 5 & 3 & 3 & 3 & 3 & 4 & 4 & 3 & 3 & 3 & 3 & 4 & 13,34 \\
\hline Lanting & 5 & 4 & 3 & 3 & 2 & 4 & 4 & 3 & 3 & 3 & 3 & 2 & 13,34 \\
\hline Jenang/dodol & 5 & 3 & 3 & 3 & 3 & 3 & 3 & 3 & 3 & 3 & 3 & 4 & 13,29 \\
\hline Noodle crackers & 4 & 3 & 3 & 2 & 3 & 3 & 4 & 3 & 3 & 3 & 3 & 3 & 13,23 \\
\hline Wood processing & 5 & 3 & 3 & 2 & 3 & 3 & 3 & 3 & 4 & 3 & 4 & 4 & 13,30 \\
\hline Wooden furniture & 5 & 3 & 3 & 2 & 3 & 3 & 3 & 3 & 4 & 3 & 4 & 4 & 13,30 \\
\hline $\begin{array}{l}\text { Bamboo } \\
\text { handcrafts }\end{array}$ & 4 & 4 & 3 & 2 & 3 & 3 & 3 & 3 & 3 & 3 & 3 & 4 & 13,26 \\
\hline Red bricks & 5 & 3 & 3 & 3 & 3 & 4 & 3 & 3 & 3 & 3 & 3 & 4 & 13,32 \\
\hline Roof tiles & 5 & 3 & 3 & 3 & 3 & 3 & 3 & 3 & 3 & 3 & 3 & 4 & 13,29 \\
\hline Weight & 0,18 & 0,147 & 0,13 & 0,064 & 0,065 & 0,084 & 0,08 & 0,054 & 0,046 & 0,051 & 0,064 & 0,034 & \\
\hline
\end{tabular}


The development of main product requires monitoring of each product set. Therefore, it takes a specific recordkeeping related to the amount of production, raw material requirements, labor absorption and amount of sales which have been conducted as evaluation materials.

\section{REFERENCES}

Alfita R. 2011. Perancangan sistem pendukung keputusan penentuan prioritas produk unggulan daerah menggunakan metode Weighted Product (WP). Jombang, [Prosiding Seminar Competitive Advantage I] Lembaga Pengembangan \& Penelitian Unipdu.

Antuli ZA. 2007. Rancang bangun sistem penunjang keputusan pengembangan agroindustri berbasis komoditas unggulan di Propinsi Gorontalo [tesis] Bogor: Institut Pertanian Bogor.

Ardiana I, Brahmayanti I, Subaedi. 2010. Kompetensi SDM UKM dan pengaruhnya terhadap kinerja UKM di Surabaya. Jurnal Manajemen dan Kewirausahaan 12(1):42-55.

Boyne S, Hall D, Williams F. 2003. Policy, support and promotion for food-related tourism initiatives: a marketing approach to regional development. Journal of Travel and Tourism Marketing 14(3-4):131-154. http://dx.doi.org/10.1300/ J073v14n03_08.

Daryanto A. 2004. Keunggulan daya saing dan teknik identifikasi komoditas unggulan dalam mengembangkan potensi ekonomi regional. Agrimedia 9(2):51-62.

Djoni, Sukandar R, 2013. Investigation of financial and value added of crystal palm sugar agro industry. International Refereed Research Journal $\operatorname{IV}(3): 8-65$.

Du Rand GE, Heath E, Alberts N. 2003. The role of local and regional food in destination marketing: a south african situation analysis. Journal of Travel \& Tourism Marketing 14(3-4):97-112. http://dx.doi.org/10.1300/J073v14n03_06.

Evalia NA. 2015. Strategi pengembangan agroindustri gula semut aren. Jurnal Manajemen \& Agribisnis 12(1):57-67.http://dx.doi.org/10.17358/ JMA.12.1.57.

Everett S, Aitchison C. 2008. The role of food tourism in sustaining regional identity: a case study of Cornwall, South West England. Journal of
Sustainable Tourism 16(2):150-167. http:// dx.doi.org/10.2167/jost696.0.

Hamzah, Marimin, Saptono IT. 2005. Strategi diversifikasi produk kayu olahan Acacia mangium (studi kasus: PT Musi Hutan Persada). Jurnal Manajemen dan Agribisnis 2(2):93-112.

Kementerian Dalam Negeri, 2014. Peraturan Menteri Dalam Negeri Republik Indonesia Nomor 9 Tahun 2014 Tentang Pedoman Pengembangan Produk Unggulan Daerah. Jakarta: Pemerintah Indonesia.

Mahmud Z. 2008. Modernisasi usaha tani kelapa rakyat. Pengembangan Inovasi Pertanian 1(4): 274-287.

Maya Banyumas. 2012. Kehangatan Tempe Mendoan Banyumas. Available at: http://www.kompasiana. com/banyumasku/kehangatan-tempe-mendoanbanyumas_551b7097a33311b228b6595c[1 Desember 2015].

Millah AN. 2013. Analisis daya saing daerah di Jawa (studi kasus: Kota Semarang, Kota Salatiga, Kota Surakarta,Kota Magelang, Kota Pekalongan, dan Kota Tegal Tahun 2009-2011), [Skripsi] Semarang: Fakultas Ekonomika Dan Bisnis Universitas Diponegoro.

Muchdie. 2000. Kompetensi Insti Sektor Unggulan di KAPET Manado-Bitung. Dalam: Suhandojo, S. H. Mukti \& Tukiyat, penyunt. Pengembangan Wilayah Perdesaan dan Kawasan Tertentu : Sebuah Kajian Eksploratif. Jakarta: Direktorat KTPW-BPPT.

Mustaufik. 2010. Pengembangan Agroindusti Gula Kelapa Kristal Sebagai Sumber Gula Alternatif. Purwokerto: Lembaga Penelitian dan Pengabdian Kepada.

Permana A. 2015. Perumusan strategi resiliensi pelaku usaha dan daya saing industri kecil menengah berbasis sumber daya lokal [Tesis] Bogor: Institut Pertanian Bogor.

Porter M. 1998. On Competition. 1sted. Massachusetts: Harvard Business School.

Pranoto S, Ma'arif S, Sutjahjo SH, Siregar H. 2006. Pembangunan perdesaan berkelanjutan melalui model pengembangan agropolitan. Jurnal Manajemen \& Agribisnis 3(1):45-53.

Salmah NNA. 2012. Pengaruh program pelatihan dan pengembangan karyawan terhadap kompetensi karyawan pada PT. Muba Electric Power Sekayu. Jurnal Ekonomi Dan Informasi Akuntansi (JENIUS) 2(3):278-290.

Slamet AS, Marimin, Arkeman Y, UdinF, 2011. Studi 
peningkatan kinerja manajemen rantai pasok sayuran dataran tinggi di Jawa Barat. Agritech 31(1):60-70.

Sukiman, Dumasari, Budiningsih S. 2007. Analisis kelayakan usaha agroindustri gula kelapa di Desa Panerusan Kulon Kecamatan Susukan Kabupaten Banjarnegara. Agritech IX(1): 3652.

Suliyanto, Suroso A, Jati DP. 2013. Potential and
Problems of Small Medium Enterprise (SMEs)coconut-sugar: case study in Banyumas Regency, Central Java-Indonesia. International Journal of Business and Management 8(3):18-26.

Tarigans DD. 2005. Diversifikasi usahatani kelapa sebagai upaya untuk meningkatkan pendapatan petani. Perspektif: Review Penelitian Tanaman Industri 4(2):71-78.

Wardani DK, Marimin, Kasutjianingati. 2015. Strategi peningkatan kualitas untuk pasar internasional melalui penerapan manajemen kualitas total: pembelajaran dari produk edamame beku. Jurnal Manajemen \& Agribisnis 12(1):36-45. http:// dx.doi.org/10.17358/JMA.12.1.36. 